\title{
Managing Talents in Higher Education Institutions: How Effective the Implementation of Succession Planning?
}

\author{
Bidayatul Akmal Mustafa Kamila*, Junaidah Hashim ${ }^{b}$ Zabeda Abdul Hamid ${ }^{b}$ \\ aSchool of Business Management, Universiti Utara Malaysia, 06010 UUM Sintok, Kedah, Malaysia \\ ${ }^{b}$ Kuliyyah of Economics and Management Sciences, International Islamic University Malaysia, 50728 Kuala Lumpur, Malaysia
}

*Corresponding author: bidayatul@uum.edu.my

\begin{abstract}
The organisations that are aware that human capital is one of their greatest treasured resources would have an impressive competitive mechanism. "Great vision without great people is irrelevant". Organisations may choose to focus on financial capital, information technology, equipment, and excellent processes; but in the end, their personnel and individual employees are the most important. The contributions of employees are undeniable. To accomplish the objectives of the National Higher Education Strategic Plan, the government is trying hard to transform Malaysian Higher Education Institutions (HEIs) with the leadership development for top and middle-level management. This study investigated the effectiveness of sucession planning in HEIs. This study employed the stratified random sampling technique from the population of academics from public universities in Malaysia. The results determine that the sample mean of succession planning at $\alpha=0.05$ level of significance concludes that succession planning at Malaysian HEIs is effective. This result might answer the capability of HEIs in practising effective succession planning. The succession process should include the identification of a successor, the designation of a successor, the selection and training of the successor, the development of a vision or strategic plan for the firm following the succession, the definition of the role of the incumbent and the communication of the decision to key stakeholders.
\end{abstract}

Keywords: Talent management, employees, sucession planning, higher education institutions (HEIs)

(C) 2016 Penerbit UTM Press. All rights reserved

\subsection{INTRODUCTION}

Delivering a good talent management strategy by implementing effective succession planning and management is very important (Rothwell, 2005). Organisations, therefore, can develop employees with the necessary talent and skills, and encourage them to serve the organisation for many years. Organisations may choose to focus on financial capital, information technology, equipment, and excellent processes; but in the end, their personnel and individual employees are the most important. Ready and Conger (2007) mentioned the effect of recognising people as the most valuable resource. Talented employees; especially those with leadership skills, should not be replaced easily. In this regard, Dreher and Dougherty (2001) suggested that high-performing organisations should introduce competitions to select their most capable employees.

This study is purposely investigated the effectiveness of sucession planning in Malaysian Higher Education Institutions (HEIs). Currently, there are 20 public universities and 23 private universities listed by the Ministry of Education (MOE) in Malaysia (MOHE, 2011a). The development of the higher education sector in Malaysia is also due to the exertions of the Malaysian government to extend the education industry internationally. Education Strategic Plan and the National Higher Education Action Plan 2007-2020 for all HEIs to accomplish actions that enhance the quality and reputation of the university. The Malaysian Ninth Plan (2006-2010) for example, delivered a series of methods to improve the quality of education, primarily through a wider coverage and application of information, communication and technology (ICT), an outline of a quality assurance system, and upgrading of infrastructure amenities (The Economic Planning Unit [The EPU], 2006). These insights are consistent with the "1 Malaysia" education key plan of the scheme that concentrates on the growth and exploitation of knowledge in line with the vision of the MOE "to establish Malaysia as a centre of excellence for higher education" (MOHE, 2011b). This study is done due to tackle a common principle among human resource professionals which argues that "great vision without great people is irrelevant", which this issues and situation might also happened among HEIs administrators.

\subsection{THEORETICAL FOUNDATION OF THE STUDY}

During the 1960s and 1970s, the higher education sector in Malaysia was strongly supported by government funding. From the building of facilities to administrative power of the institutions, they are all initiated by the Malaysian Government through the Ministry of Education. At that time, the chief administrator only needs to administrate the policies on HEIs development by focusing on the development and evaluation of curriculum, teaching and learning in the classroom, management planning staff, students and parents. They were just 
managing budget, adding the required skills in their public relations and seeking cooperation grants and donations. Nevertheless, the challenges of higher education in Malaysia today are to generate better performance. The challenge is not only to increase the number of graduates, but also to increase the quality of graduates. The required skill set of academic leadership in the last fifty years is very different from today's academic leaders. Therefore, a quality human capital and leadership should be the key to successful HEIs (Mateso, 2010).

HEIs are unique organisations that tend to focus on services to students or the community. HEIs have different purpose of the business institutions that put profit as the main priority. As HEIs are the backbone of human capital development, it is important to address the question of their leader replacement; as the lack of succession planning efforts, can subtly undermine the quality of academic institutions. Quality of academic leadership in HEIs will be a major competitive advantage in the success of the institution (Kezar and Eckel, 2004; Mateso, 2010). Should HEIs implement succession planning with the exact level as those businesses that have made the continuity of leadership sustainability and longevity of the business?

How can HEIs manage the succession planning practices? Academic leaders are central pillars of HEIs' administrators. How are these leaders guided through the transition? Gmelch (2004) proved that academic leaders in HEIs typically entered into their positions lacking of leadership preparation or previous executive experience, without a strong idea of their role and deprived of recognition except for academic performance. A serious shortage of qualified leadership requires HEIs to choose a qualified candidate. This critical leadership problem requires a systematic process of recruitment by the administrator of HEIs (Barden, 2006).

Instead, HEIs are facing an augmented demand for administrative leadership. Succession planning is a key issue for HEIs when voluntary and involuntary turnover of personnel include a major proportion of senior staff and administrators in organisations. Every industry or institution has its own set of circumstances concerning the aging workforce and possible retirements of its senior leaders (Kezar and Eckel, 2004). However, there's a heightened concern with the HEIs' capacity to meet the leadership necessity if senior leaders that possess certain skills and abilities were to retire. HEIs are conventionally a very bureaucratic atmosphere, particularly when it moves toward employment practices. According to Boggs (2003), the top leadership positions at HEIs are traditionally developed over the ranks as administrators and management of faculty. These pools of future leaders are also beginning to decrease as the employees are not necessarily moving to the next level of leadership and are reaching retirement age themselves.

There are other negative implications that also arise when the new appointments are made at HEIs. Many HEIs' academic leaders are directors to heads of department who are holding positions for a short duration of time. According to Fulmer and Conger (2004), when an employee leaves the office for the last time, the experience he or she acquired at the organisation at considerable cost will literally walk out of the door with them. If this case happened to HEIs, the institutions will have to induct new individuals from scratch. This is because the replacement of employees that were sourced externally will not have comprehensive knowledge, skills and experience that particular HEIs demands. Even if the replacement comes from within HEIs, the person will still have to be inducted into the new job.

\subsection{CONCEPTUAL FRAMEWORK}

According to Rothwell (1994), Henri Fayol was the first to introduce succession planning and he believed that if succession-planning needs are ignored, organisations would not be prepared to make necessary transitions. There few definitions of succession planning that can be compared and considered (Sharma, Chrishman and Chua 2003). According Oxford Advanced Learner's Dictionary of Current English (2005), succession planning is defined as a process of training and preparing employees in a company or an organisation so there will always be somebody to replace a senior manager who leaves. This definition relates to the operations of an organisation or department in order to recognize professional development among employees especially when there are job advancements and replacements. Rothwell (2005) argued that succession planning has often been referred to as a replacement planning but it is not. In essence, replacement planning is a form of risk management whereas succession planning is a proactive, deliberate form of employee development over time.

Defined by McCauley and Wakefield (2006), succession planning is a process that leads management to define and address talent management strategies. According to them, succession planning prepares the organisation and people for the future hence; the organisation has to ensure their people are properly valued, nurtured, and developed. In Sharma et al. (2003), they defined the succession process as one that takes place over a long duration of term and includes many activities. The succession process includes the identification of a successor, the designation of a successor, the selection and training of the successor, the development of a vision or strategic plan for the firm following the succession, the definition of the role of the incumbent and the communication of the decision to key stakeholders.

Greengard (2001) asserted that succession planning is not an easy task as "mapping out the future involves more than an organisational chart displaying the corporate hierarchy" (p. 34). Succession planning is a process that helps to ensure the stability of an organisation. All organisations either large or small should realize the importance of succession planning. In this research study, the definition coined by Rothwell (1994) is emphasised. According to Rothwell (1994), "succession planning is perhaps best understood as any effort designed to ensure the continued effective performance of an organisation, division, department, or work group by making provision for the development and replacement of key people over time. Its purpose is to ensure leadership continuity in key positions and encourage individual advancement (p. 5-6)".

Succession planning looks like developing a roster of candidates to cover all key positions within the organisation. In Carter (1986), succession planning describes management positions to provide maximum flexibility in lateral management moves and to ensure that individuals achieve greater seniority. He also asserted that management skills are broadened and become more generalized in relation to total organisational objectives rather than purely departmental objectives. While Collins (2001) and Feeney (2003) also explained that through employee development, the company is guaranteed to have any talent needed available in-house, and the employees are encouraged because they are growing, expanding their skills and rounding out their resumes. It is not just about "designating a prince to be crowned king" (Feeney, 2003, p. 40), it is also a tool to ensure the right people with the right skills are sitting in the right place at the right time to meet the organisation need over time (Rothwell, 2005).

Succession planning and management need not be confined merely to fill management positions or management staff. Effective succession planning and management efforts need to back up critical and personal development of employees in any job category, including those important in professional sales, technical, clerical, and promotion of production (Rothwell, 2005). Organisations need to 
take action to ensure that recruited workers constantly move forward in their careers and become a major and potential role within the organisation. By implementing succession planning, organisations will create their own benefits (Rothwell, 2005, p. 31):

1. Allowing the organisation to assess the needs of talent by creating job descriptions and job competency models;

2. Allowing leaders to identify, record, retain key employees to fill critical job functions;

3. Providing avenues for succession planning now and forward through a discussion of how to develop talent;

4. Defining the career path through the organisation;

5. Preparing for higher returns on investments from the employees;

6. Leading to the appointment of a suitable position and pre-selection for people to meet organisational goals.

In addition, Henderson (2006) also stated that there are three main reasons organisations should implement a systematic succession planning to provide opportunities for improvement for "high potential" employees; to provide employees the required training, education and staff development programs; and to improve talent pool.

Organisations should not treat their succession plans as legacy documents because succession planning is more than that. An organisation will find the risk of losing the continuity of human resources and the opportunity to revitalize their organisations. Friedman (1986) suggested that succession planning would be more successful if they are done with a very formal, a systematic, balanced system, and adequately resourced, efficient, reliable staff.

\subsection{METHODOLOGY}

Meant for this study, the researcher targeted the research population to be among HEIs employees mainly from the public universities. According to Jabatan Pengajian Tinggi (2011), public universities in Malaysia are characterised into three groups, specifically Research Universities (RU), Comprehensive Universities (CU) and Focus Universities (FU). This study employed the stratified random sampling technique. The initial plan for total responses should be 400 academics of those universities but usable rate of returned questionnaires were 399. Yet, the total respondents that should represent the population already exceeded more than enough of the required sample size $(\mathrm{N}=377$ to 379) as suggested by Kierje and Morgan (1970).

The questionnaire for effective succession planning and management was based on Rothwell (2005). There are 20 items using the Likert scale 1 to 5. Cronbach's alphas were calculated for the variables of succession planning in order to examine the reliability and internal consistencies. The value among 399 respondents with Cronbach's alphas of 0.911 should be acceptable for the next test.

The researcher used one sample t-test to ascertain the degree of effectiveness of succession planning at HEIs. The purpose of the one sample t-test is to determine whether there is sufficient evidence to conclude that the mean of the population from which the sample is taken is different from the specified value. One sample t-test compares mean scores on the value of the known sample, usually the population mean (the average for the population yield some benefits) (Sekaran, 2003). The basic idea is of the average comparison test sample (observed average) and population (expected average), with adjustment for the number of characters in the sample and the standard deviation of the norm.

\subsection{RESULTS AND DISCUSSION}

The objective of this study is to investigate the level of succession planning effectiveness at Malaysian HEIs. Greengard (2001) declared that succession planning stands as a difficult job since "mapping out the future involves more than an organisational chart displaying the corporate hierarchy" (p. 34). It is to make sure the right people with the right skills are sitting in the right places at the right time to meet the organisations' necessities (Rothwell, 2005).

There were 20 items on succession planning in the questionnaire distributed to the respondents for the survey. Table 2 displays significant difference of averages for items SP1, SP2, SP3, SP4, SP5, SP6, SP7, SP8, SP9, SP10, SP11, SP12, SP13, SP14, SP15, SP16, SP17, SP18, SP 19, and SP20. The results show that each of SP items was not significantly different from 3 (somewhat effective) with $\mathrm{t}(398)=5.960$ to 26.646 , with $\mathrm{p}=0.000$ for overall items SP1 to SP20. The $95 \%$ confidence interval on means of all succession planning items using the academics' distribution with 398 degrees of freedom which were between the lowest bound of 3.1428 to the most upper bound of 3.7993 were reported in Table 1.

Succession planning should be carried out by developing capabilities of employees as it underpins what the organisation would like to achieve in the future. Coming up with a competency model provides HEIs an opportunity to thoroughly examine and define specific knowledge; skills and abilities sought in future leaders (Rothwell, 2005). The results determine that the sample mean of succession planning at $\alpha=0.05$ level of significance concludes that succession planning at Malaysian HEIs is effective. This result might answer the capability of HEIs in practising effective succession planning. However, HEIs should not treat their succession plans as only legacy documents since succession planning is more than that. According to Friedman (1986), succession planning will be more efficacious if they are ready with an official, systematic and well-adjusted structure, and sufficiently resourced, competent and trustworthy staff. Thus, the objective is accomplished. 
Table 1 One-sample statistics to determine effectiveness of succession planning

\begin{tabular}{lllcccc}
\hline & N & Mean & Std. Deviation & Std. Error Mean & \multicolumn{2}{c}{ 95\% Confidence Interval for Mean } \\
\cline { 6 - 7 } & & & & & Lower Bound & Upper Bound \\
\hline SP1 & 399 & 3.7444 & .55800 & .02794 & 3.6894 & 3.7993 \\
SP2 & 399 & 3.5539 & .59856 & .02997 & 3.4950 & 3.6128 \\
SP3 & 399 & 3.4612 & .72837 & .03646 & 3.3895 & 3.5328 \\
SP4 & 399 & 3.2130 & .71399 & .03574 & 3.1428 & 3.2833 \\
SP5 & 399 & 3.3634 & .73036 & .03656 & 3.2915 & 3.4353 \\
SP6 & 399 & 3.4035 & .67257 & .03367 & 3.3373 & 3.4697 \\
SP7 & 399 & 3.4987 & .69048 & .03457 & 3.4308 & 3.5667 \\
SP8 & 399 & 3.4461 & .68837 & .03446 & 3.3784 & 3.5139 \\
SP9 & 399 & 3.3584 & .76963 & .03853 & 3.2826 & 3.4341 \\
SP10 & 399 & 3.4787 & .72217 & .03615 & 3.4076 & 3.5498 \\
SP11 & 399 & 3.6291 & .62828 & .03145 & 3.5672 & 3.6909 \\
SP12 & 399 & 3.6291 & .60380 & .03023 & 3.5696 & 3.6885 \\
SP13 & 399 & 3.5815 & .63226 & .03165 & 3.5192 & 3.6437 \\
SP14 & 399 & 3.5689 & .59701 & .02989 & 3.5102 & 3.6277 \\
SP15 & 399 & 3.5489 & .59899 & .02999 & 3.4899 & 3.6078 \\
SP16 & 399 & 3.4586 & .70367 & .03523 & 3.3894 & 3.5279 \\
SP17 & 399 & 3.4236 & .64078 & .03208 & 3.3605 & 3.4866 \\
SP18 & 399 & 3.4862 & .62541 & .03131 & 3.4247 & 3.5478 \\
SP19 & 399 & 3.3835 & .65034 & .03256 & 3.3195 & 3.4475 \\
SP20 & 399 & 3.3058 & .68856 & .03447 & 3.2380 & 3.3735 \\
\hline
\end{tabular}

Table 2 One-sample test to determine the effectiveness of succession planning

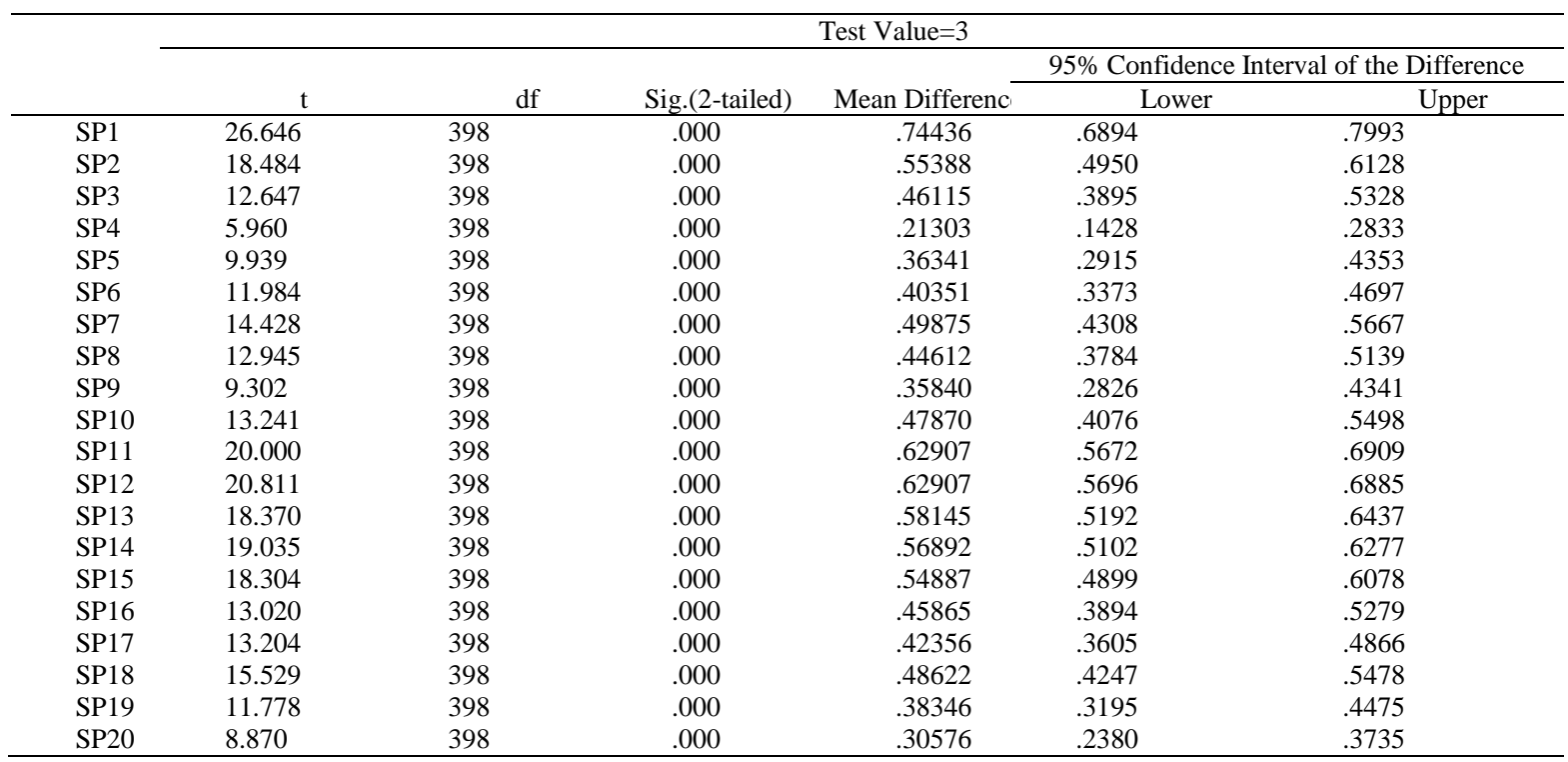

In order to identify the effectiveness of succession planning at HEIs, the respondents' working profile was also being identified in this research (refer to Table 3). According to the results, most of the respondents have 5-10 years' experience (36.1\%) in the current organisations. Then, followed by 11-20 years' experience (32.6\%) and below five years' experience (27.1\%). The researcher also managed to identify 17 respondents who have 21-30 years working experience in their organisations.

The respondents' total working experience at the current and previous organisations can most probably be assumed as follows: 21-30 years (48 respondents), 11-20 years (131 respondents), 5-10 years (115 respondents), and below five years (99 respondents). Six academics noted the maximum number of experience that was more than 31 years.

From the responses, most academics took at least five years to be in their current career position (41.4\%). Most of them were lecturers who successfully graduated with a doctoral degree. At average, some of them needed 5-10 years (35.3\%) and 11-20 years $(32.8 \%)$. Only eight respondents chose more than 21 years career achievement.

A plan for retirement is very important in managing human capital in organisations. This study indicates that 255 respondents will retire after 15 more years of service. There were 23 respondents who will retire soon (within 5 years) while the other 121 respondents planned to retire within $6-15$ years. 
Table 3 Summary of working profile $(\mathrm{N}=399)$

\begin{tabular}{|c|c|c|}
\hline & Respondents (N) & $\begin{array}{c}\text { Percentage } \\
(\%)\end{array}$ \\
\hline \multicolumn{3}{|c|}{ Working Experience (with current organisations) } \\
\hline Below 5 years & 108 & 27.1 \\
\hline $5-10$ years & 144 & 36.1 \\
\hline 11- 20 years & 130 & 32.6 \\
\hline 21- 30 years & 17 & 4.3 \\
\hline \multicolumn{3}{|c|}{ Total Working Experience (including previous organisations) } \\
\hline Below 5 years & 99 & 24.8 \\
\hline $5-10$ years & 115 & 28.8 \\
\hline $11-20$ years & 131 & 32.8 \\
\hline $21-30$ years & 48 & 12.0 \\
\hline More than 31 years & 6 & 1.5 \\
\hline \multicolumn{3}{|c|}{ Career Achievement for Current Position } \\
\hline Below 5 years & 165 & 41.4 \\
\hline $5-10$ years & 141 & 35.3 \\
\hline $11-20$ years & 85 & 21.3 \\
\hline $21-30$ years & 7 & 1.8 \\
\hline More than 31 years & 1 & 0.3 \\
\hline \multicolumn{3}{|l|}{ Retirement Plan } \\
\hline In the next $0-5$ years & 23 & 5.8 \\
\hline In the next $6-10$ years & 41 & 10.3 \\
\hline In the next $11-15$ years & 80 & 20.1 \\
\hline In more than 15 years & 255 & 63.9 \\
\hline \multicolumn{3}{|c|}{ Planning of Changing Employment/ Workplace } \\
\hline Yes & 27 & 6.8 \\
\hline No & 181 & 45.4 \\
\hline Maybe & 191 & 47.9 \\
\hline
\end{tabular}

This study also asked the respondents concerning their loyalty towards their current organisations. They were asked whether they want to stay, move out or thinking of moving out from the organisations. Surprisingly, most of the respondents (47.9\%) answered "maybe" which means they are thinking about moving out even not it is not yet confirmed. Only $6.8 \%$ of the respondents confidently answered "yes" to change their employment in the future. The small number could not challenge the majority of 181 respondents (45.4\%) who confirmed that they would not leave the organisations. Table 4, those who were mostly planned to change employment, not to change employment and maybe change employment are among lecturers as they were the majority of academic staff in HEIs. But none of associate professors or professors were intent to change from current HEIs to the new one. Most of them may have already build strong career development and feel comfortable with their career achievement in the organisations.

Table 4 Cross tabulation of current position and intention to change employment among heis academics

\begin{tabular}{|c|c|c|c|c|c|}
\hline & & \multicolumn{3}{|c|}{ Change of Employment } & \multirow[b]{2}{*}{ Total } \\
\hline & & Yes & No & Maybe & \\
\hline \multirow{5}{*}{$\begin{array}{l}\text { Current } \\
\text { Position }\end{array}$} & Tutor & 7 & 27 & 32 & 66 \\
\hline & Lecturer & 19 & 114 & 149 & 282 \\
\hline & Associate Professor & 0 & 18 & 12 & 30 \\
\hline & Professor & 0 & 10 & 1 & 11 \\
\hline & Other & 0 & 5 & 3 & 8 \\
\hline Total & & 26 & 174 & 197 & 397 \\
\hline
\end{tabular}

\subsection{CONCLUSION}

According to the results, academics at HEIs agreed that succession planning are effective. HEIs as garden of knowledge which produce valuable human capital should create successful human resource practices by implementing talent management practices and succession planning to sustain the quality of academics and their continuous excellent performance and growth. Malaysia is now facing great environmental challenges in education industry, particularly in higher education. The useful guidelines for human resource management practices in the present and future Malaysian HEIs can be outlined based on the results of this study. The technological advancements that bring about a new era of knowledge acquisition and business-oriented objectives in the education sector have to lead HEIs in Malaysia to move forward and aligned with the innovation. Thus, HEIs should consider as many options as possible in retaining employees while 
securing their trust and loyalty, as the foundations of the relationships within the organization and to meet the goals of HEIs employees without losing sight of the Ministry of Education (MOE)'s mission and vision. Therefore, by presenting this study, it is hoped that this research may be used by HEIs as well as the ministry as a platform to emphasize further decision into the issue of having strategic human resource management such as effectiveness of succession planning.

Higher Education Leadership Academy (AKEPT) is an organisation under the Ministry of Education (MOE) of Malaysia which is concerned about HEI leaders (Higher Education Leadership Academy [AKEPT], 2014). To accomplish the objectives of the National Higher Education Strategic Plan, the government is trying hard to transform HEIs with the leadership development for top and middlelevel management. AKEPT, which was launched in January 2000, is hoped to take serious action in the development of Malaysian HEIs' human capital, since HEIs are not implementing succession planning efficiently as yet.

\section{References}

Barden, D. M. (2006, March 17). The Internal Heir Apparent: Succession Planning Is All The Rage In The Corporate Sector, So Why Not In Higher Education? [Electronic version]. The Chronicle of Higher Education. Retrieved February 10, 2010 from www.chronicle.com.

Boggs, G. R. (2003). Leadership context for the twenty-first century. In W. E. Piland \& D. B. Wolf (Eds.), Help Wanted: Preparing Community College Leaders in A New Century (pp. 15-25). San Francisco: Jossey-Bass.

Carter, N. (1986). Guaranteeing Management's Future Through Succession Planning. Journal of Information Systems Management, 3(3), 13-14.

Collins, J. (2001). Good to Great. New York: HarperCollins.

Dreher, G.F \& Dougherty, T.W. (2001). Human Resource Strategy: A Behavioral Perspective for the General Manager. Singapore: McGraw Hill

Feeney, S. (2003). Irreplaceable you. Workforce Management, 82(8), 36-40.

Friedman, S.D. (1986). Succession Systems in Large Corporations: Characteristics and Correlates of Performance. Human Resource Management, 2(5), 191-214.

Fulmer, R. M., \& Conger, J. A. (2004). Developing Leaders with 2020 Vision. Financial Executive, 20(5), 38-41.

Gmelch, W. H. (2004). The Department Chair's Balancing Acts. New Directions for Higher Education, 124, 68-84

Greengard, S. (2001). Why Succession Planning Can't Wait. Workforce, 80(12), 34-38.

Handerson, J. (2006). The Value Of Succession Planning. Leadership Advanced Online. VII, 1-2.

Higher Education Leadership Academy (AKEPT) (2014). AKEPT in Brief. Retrieved on November 19, 2014 from http://akept.demosite.my/index.php/en/corporateinfo/about-akept.

Kezar, A., \& Eckel, P. (2004). Meeting Today's Governance Challenges: A Synthesis Of The Literature And Examination Of A Future Research Agenda. The Journal of Higher Education, 75(4), 371-400.

Krejcie, R. V., \& Morgan, D. W. (1970). Determining Sample Size For Research Activities. Educational and Psychological Measurement. 30(3). 607-610.

Mateso, P. (2010). Understanding Succession Planning And Management Efforts At Midwestern University: A Mix Method Study. OhioLink ETD Center. 1276203234. Retrieved on January 16, 2013 from https://etd.ohiolink.edu/ap:10:0::NO:10:P10_ETD_SUBID:49443.

McCauley, C, \& Wakefield, M. (2006). Talent management in the 21st century: Help Your Company Find, Develop And Keep Its Strongest Workers. The Journal for Quality \& Participation, 29(4), 4-7.

Ministry of Higher Education (2011a). Laporan Statistik Pelajar. Retrieve on January 20, 2011 from http://www.mohe.gov.my/web_statistik/index.htm.

Ministry of Higher Education (2011b). Introduction - Ministry of Higher Education (MOHE). Retrieve on January 20 , 2011 from http://www.mohe.gov.my/educationmsia/index.php?article=mohe.

Oxford Advanced Learner's Dictionary of Current English (2005). Oxford: Oxford University Press

Ready, D. A., \& Conger, J. A. (2007). Make Your Company A Talent Factory. Harvard Business Review, 85(6), 68-77.

Rothwell, W. J. (1994). Effective Succession Planning: Ensuring Leadership Continuity And Building Talent From Within. New York: AMACOM.

Rothwell, W. J. (2001). Effective Succession Planning: Ensuring Leadership Continuity and Building Talent from Within (2 ${ }^{\text {nd }}$ Edition). New York: American Management Association

Rothwell, W. J. (2005). Effective Succession Planning: Ensuring Leadership Continuity and Building Talent from Within (3 ${ }^{\text {rd }}$ Edition). New York: American Management Association.

Sekaran, U. (2003). Research Methods for Business; A skill Building Approach (4 ${ }^{\text {th }}$ Edition). New York, NY: Wiley.

Sharma, P., Chrisman, J.J. \& Chua, J.H. (2003). Succession Planning As Planned Behavior: Some Empirical Results. Family Business Review, 16(1), 1-15.

The Economic Planning Unit (2006). Ninth Malaysian Plan 2006-2010. Putrajaya: Prime Minister Department. 